\title{
Mathematical modelling of the propagation of accidental oil spills when designing an artificial beach in Svetlogorsk, Kaliningrad region
}

\author{
K.N. Makarov ${ }^{1, *}$ and I.L. Makarova ${ }^{1}$ \\ ${ }^{1}$ Sochi State University, 94, Plastunskaya st., 354000, Sochi, Russia
}

\begin{abstract}
The article deals with the issues of mathematical modeling of the transformation and drift of an oil product spill in case of possible ship accidents both in the shallow sea zone at depths of $25-30 \mathrm{~m}$, and in the surf zone at depths of 3-5 m. The method for modeling the drift of an oil product slick under the influence of waves and currents is presented. The most dangerous hydro-meteorological situations from the point of view of liquidation of the consequences of accidents are considered and the simulation of the drift of oil pollution is carried out. The research results make it possible to develop optimal plans for the elimination of oil spills.
\end{abstract}

\section{Introduction}

The project site is located on the Kaliningrad coast of the Baltic Sea in the city of Svetlogorsk between the existing descent to the beach in the village Otradnoe and Baltic street, and includes the Svetlogorsk Bay. The total length of the section is about $4500 \mathrm{~m}$ - Figure 1.

The project envisages the creation of an artificial sandy beach with a width of at least 70 $\mathrm{m}$ in the upper part (in calm weather), providing damping of waves, stability of the promenade and recreational requirements. The beach is supposed to be created by sand reclamation from an underwater quarry located to the NE from the project site at depths of 26 - 28 m - Figure 2.

To prepare the project, an Engineering Survey program was developed, including hydrographic work with the sampling of bottom sediments from the research vessel "Akademik Nikolay Strakhov" in the area of an underwater quarry.

During engineering and geological surveys for drilling wells in the sea in the places of the proposed construction of groins and breakwaters, a BPU-2 drilling rig is used, installed on a non-self-propelled pontoon. The pontoon is transported by the "Kalmar" tug.

For the development of an underwater sand quarry, beach reclamation and the development of underwater trenches for hydraulic structures, it was planned to use the dredger ship "Brabo".

\footnotetext{
* Corresponding author: ktk100@ mail.ru
} 
Thus, when carrying out engineering surveys and arranging the beach, various types of floating craft will be used, both in the water area of an underwater quarry, and in the coastal zone of beach reclamation and construction of beach-holding structures

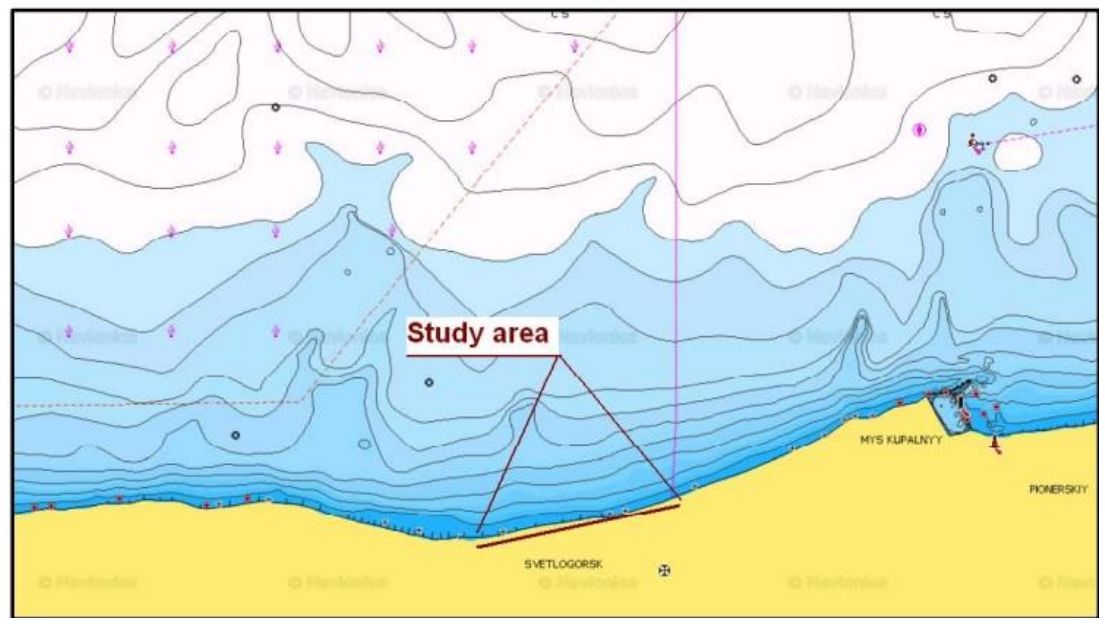

Fig. 1. Situational plan of the beach reclamation project site location.

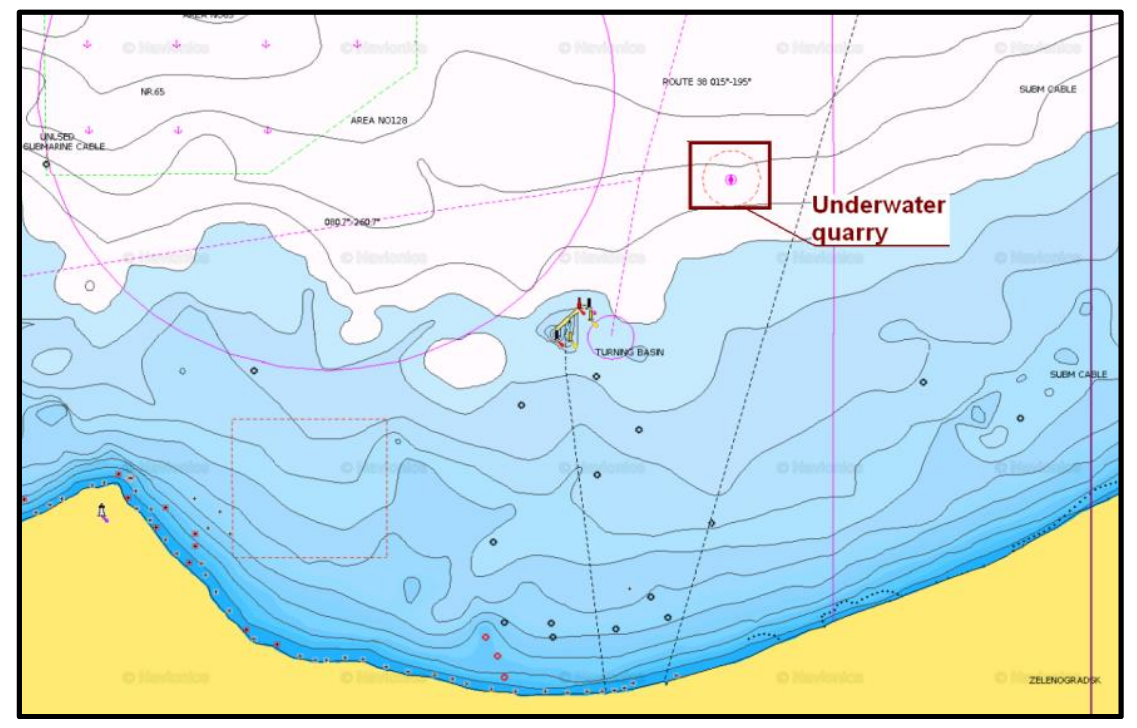

Fig. 2. Location of the underwater sand quarry.

The use of floating craft in the sea area can be accompanied by various emergency situations. The most dangerous from the point of view of environmental damage is an oil spill when a ship's fuel tank is depressurized.

After an accidental spill, the oil product will spread over the sea area and drift under the influence of wind and currents. In this case, pollution of the coastline with oil products is possible.

According to the decisions of the Government of Russia, for the assessment of such emergencies, it is assumed that as a result of the accident, $100 \%$ of the fuel will escape from the largest tank of the vessel.

The purpose of this work was to simulate the transformation of an accidental oil spill in the water area of an underwater quarry and in the coastal zone of the sea, as well as its drift 
when performing the main types of survey and construction work associated with the use of floating craft. At the same time, according to the project documentation, the fight against an accidental oil spill should begin no later than 4 hours after the accident.

\section{Materials and methods}

Mathematical modeling was carried out according to programs [1-3] that implement the normative and recommended in the Russian Federation methods for calculating the generation of waves and currents by the wind [4-12], transformation and drift of accidental oil spills [13-21].

To carry out the calculations, digital models of the coastal zone of the beach reclamation and the section of the underwater quarry were developed.

When studying the processes occurring with oil or other oil products in the sea, oil fractions are combined into one formal pseudo-fraction. An oil product that gets into water undergoes various physical, chemical and biological transformations due to contact with water and air, which leads to a change in its composition and properties [14, $19-21]$.

In the sea, an oil product can be in various states:

- molecular film;

- film up to several mm thick (slick);

- emulsion "water in oil" or "oil in water";

- bottom sediments, oil dissolved in water, oil aggregates.

The behavior of an oil product that gets into the sea depends on its physical and chemical properties, as well as on environmental conditions: wind and wave conditions, currents, the number of oil-oxidizing bacteria, air and water temperatures.

Having reached the shore, the oil product, depending on its structure, can behave as follows:

- stick to rocks and coastal structures;

- accumulate by a thick film in the tidal zone;

- to penetrate between stones to a depth of $1 \mathrm{~m}$;

- mix with mineral and plant particles, forming oil "cakes";

- to be reflected from the coast in a certain amount, remaining on the sea surface.

The contact of the oil slick with the shore significantly complicates the response measures, and also leads to an increase in the environmental hazard of oil spills [13 - 18]. Therefore, the most important task in liquidation activities is to prevent contact of the oil slick with the shore and to collect the spilled oil from the water surface.

The main physical and chemical changes in oil under the influence of external factors include evaporation, emulsification, and dissolution in water, photo oxidation and biodegradation $[13,20]$.

Propagation (drift) - the process of the oil slick offset. It arises under the influence of winds and currents. The oil product drifts at a speed that is several percent of the wind speed. According to rough estimates, the speed of movement of the oil slick is $60 \%$ of the current speed and $3-4 \%$ of the wind speed [13 - 16].

In order to establish which weather conditions are the most unfavorable from the point of view of the spread of the spot in the water area, a special study was carried out in [13].

The analysis of the data obtained made it possible to conclude that the most unfavorable weather conditions in terms of the spread of an oil slick in the water area are the following: wind at a speed of $11-12 \mathrm{~m} / \mathrm{s}$ and a passing current of $0.3 \mathrm{~m} / \mathrm{s}$.

If "worst-case conditions" are understood in terms of the largest amount of funds required to collect an oil slick, then it is obvious that in this context, more booms, vessels for their delivery, and oil-gathering systems will be needed if the slick is in the shape of a circle. 
If there is a significant wind impact, the slick takes the shape of an ellipse and its localization is easier, since it is enough to install a smaller number of booms perpendicular to the slick's motion vector. On the other hand, in calm weather, surface tension forces hold the stain and the spreading process is not intense enough.

When the wind speed is less than $5 \mathrm{~m} / \mathrm{s}$, the shape of the spot differs little from the round one. It is for this reason that the maximum amount of spill containment means is required in low wind conditions. At wind values of more than $15 \mathrm{~m} / \mathrm{s}$, the spot quickly stretches into an ellipse and its localization becomes easier.

From the point of view of the amount of equipment involved in the oil spill liquidation operation, the most unfavorable weather conditions should be recognized as a wind with a speed of $5 \mathrm{~m} / \mathrm{s}$ and a passing current of $0.1 \mathrm{~m} / \mathrm{s}$.

The rate of transfer of individual spots of oil product on the sea surface Ua is usually described by the relation [20]:

$$
U a=U w+U c(W)+U s+U s e,
$$

where $\mathrm{W}$ is the wind speed over the oil slick, $\mathrm{m} / \mathrm{s}$; Uw - stationary flow velocity, $\mathrm{m} / \mathrm{s}$; $\mathrm{Uc}(\mathrm{W})$ - speed of drift current, is $2-3 \%$ (wind coefficient) of wind speed, $\mathrm{m} / \mathrm{s}$; Us - speed of transfer due to waves, $\mathrm{m} / \mathrm{s}$; Use - correction factor due to turbulent diffusion processes, $\mathrm{m} / \mathrm{s}$.

If the flow rate is not uniform, then the shape of the oil product spot from circular at 1 step gradually turns into a kind of irregular spot.

The calculation algorithm implemented in the corresponding computer program is as follows (Figure 3) [4]:

1. By given coordinates of the center of the spill Xo, Yo, the volume of the spill $\mathrm{W}$ and given storm time DT, the following are determined:

- time calculation step Dst $=$ DT/9 (that is, the storm time is divided into 9 time intervals);

- the radius $\mathrm{R}$ and the area $\mathrm{S}$ of the initial spreading of the oil product are determined;

- the initial coordinates of 8 points are calculated that approximate the initial spill spot at the calculation step of 1 :

$$
\begin{aligned}
& \mathrm{X} 1,1=\mathrm{Xo}, \mathrm{Y} 1,1=\mathrm{Yo}+\mathrm{R} ; \\
& \mathrm{X} 1,2=\mathrm{Xo}+\mathrm{R} \times 0.707, \mathrm{Y} 1,2=\mathrm{Yo}+\mathrm{R} \times 0.707 \\
& \mathrm{X} 1,3=\mathrm{Xo}+\mathrm{R}, \mathrm{Y} 1,3=\mathrm{Yo} ; \\
& \mathrm{X} 1,4=\mathrm{Xo}+\mathrm{R} \times 0.707, \mathrm{Y} 1,4=\mathrm{Yo}-\mathrm{R} \times 0.707 \\
& \mathrm{X} 1,5=\mathrm{Xo}, \mathrm{Y} 1,5=\mathrm{Yo}-\mathrm{R} ; \\
& \mathrm{X} 1,6=\mathrm{Xo}-\mathrm{R} \times 0.707, \mathrm{Y} 1,6=\mathrm{Yo}-\mathrm{R} \times 0.707 \\
& \mathrm{X} 1,7=\mathrm{Xo}-\mathrm{R}, \mathrm{Y} 1,7=\mathrm{Yo} \\
& \mathrm{X} 1,8=\mathrm{Xo}-\mathrm{R} \times 0.707, \mathrm{Y} 1,8=\mathrm{Yo}+\mathrm{R} \times 0.707 \\
& \text { where } \sin \left(45^{\circ}\right)=\cos \left(45^{\circ}\right)=0.707
\end{aligned}
$$

2. The components of the transfer velocity are calculated at points $1-8$ at the calculation step i

$\mathrm{Ui}, 1=\mathrm{Umi}, 1, \mathrm{Vi}, 1=\mathrm{Vmi}, 1+\mathrm{Vspr}$;

$\mathrm{Ui}, 2=\mathrm{Umi}, 2+\mathrm{Vspr} \times 0.707, \mathrm{Vi}, 2=\mathrm{Vmi}, 2+\mathrm{Vspr} \times 0.707$;

$\mathrm{Ui}, 3=\mathrm{Umi}, 3+\mathrm{Vspr}, \mathrm{Vi}, 3=\mathrm{Vmi}, 3$;

$\mathrm{Ui}, 4=\mathrm{Umi}, 4+\mathrm{Vspr} \times 0.707, \mathrm{Vi}, 4=\mathrm{Vmi}, 4-\mathrm{Vspr} \times 0.707$;

$\mathrm{Ui}, 5=\mathrm{Umi}, 5, \mathrm{Vi}, 5=\mathrm{Vmi}, 5-\mathrm{Vspr}$;

$\mathrm{Ui}, 6=\mathrm{Umi}, 6-\mathrm{Vspr} \times 0.707, \mathrm{Vi}, 6=\mathrm{Vmi}, 6-\mathrm{Vspr} \times 0.707$;

$\mathrm{Ui}, 7=\mathrm{Umi}, 7-\mathrm{Vspr}, \mathrm{Vi}, 7=\mathrm{Vmi}, 7$;

$\mathrm{Ui}, 8=\mathrm{Umi}, 8-\mathrm{Vspr} \times 0.707, \mathrm{Vi}, 8=\mathrm{Vmi}, 8+\mathrm{Vspr} \times 0.707$,

where Umi, 1 ... .Umi, $8, \mathrm{Vmi}, 1 \ldots$ Vmi,8 are the components of the drift flow velocity at the points of approximation of the spill spot, Vspr - spot spreading rate. 


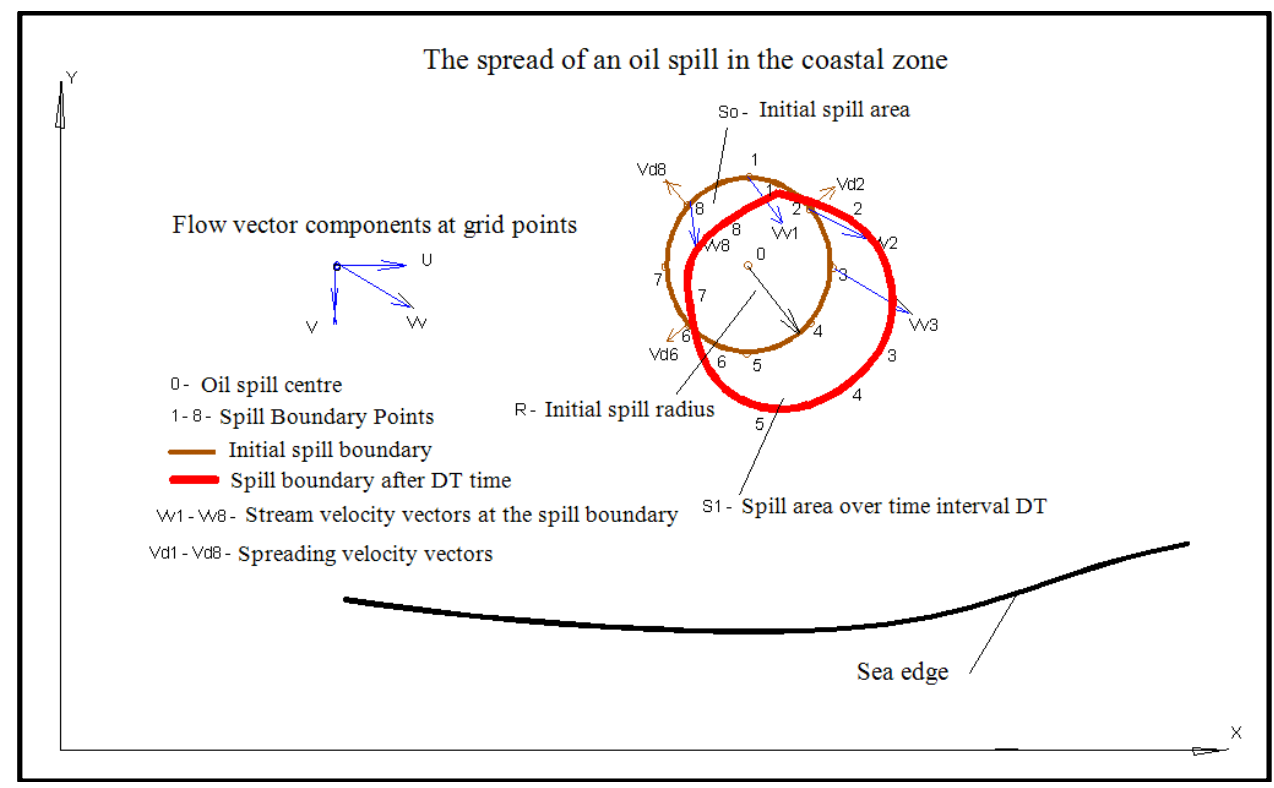

Fig. 3. Scheme for modeling the spread of an oil product spill.

3. New coordinates of the spill spot approximation points are calculated at the calculation step $\mathrm{i}+1$ for points $\mathrm{j}=1 \ldots 8$ :

$$
X i+1, j=X i, j+K k l x D s t \times U i, j ; \quad Y i+1, j=Y i, j+K c l y D s t \times V i, j,
$$

where Kklx, Kkly are calibration coefficients determined from natural or experimental data. In the absence of such data, the values of these coefficients are taken equal to 1 .

4. The new area of the spill spot is calculated

$$
S_{i+1}=0.5 \sum_{1}^{n} Y_{i}\left(X_{i-1}-X_{i+1}\right)
$$

where $\mathrm{n}=1 \ldots 8$ is the number of spill spot approximation points.

5. If the time step is $i<=9$, then go to step 2 .

In accordance with the above theoretical provisions, the following were taken as the most unfavorable hydro meteorological situations:

1. For the area of an underwater quarry. Wind from NNE direction at a speed of $11 \mathrm{~m} / \mathrm{s}$ with a continuous duration of 12 hours. In this situation, the oil spill spot from the area of the underwater quarry will drift towards the coast along the shortest distance.

2. For the area of an underwater quarry. Wind from NNE direction at a speed of $5 \mathrm{~m} / \mathrm{s}$ with a continuous duration of 12 hours. In this situation, the oil spill spot will spread in the area of the underwater quarry to a maximum area and, accordingly, have a maximum perimeter.

3. For the coastal zone of beach reclamation, drilling operations during exploration, development of trenches for the construction of hydraulic structures. Wind from WNW direction at a speed of $11 \mathrm{~m} / \mathrm{s}$ with a continuous duration of 12 hours. In this situation, the oil spill spot will drift as far as possible along the coast.

4. For the coastal zone of beach reclamation, drilling operations during surveys, development of trenches for the construction of hydraulic structures. Wind from $\mathrm{N}$ direction at a speed of $5 \mathrm{~m} / \mathrm{s}$ with a continuous duration of 12 hours. In this situation, the oil spill spot will spread in the work area to the maximum area and, accordingly, have a maximum perimeter. 
Examples of calculations of the fields of waves and currents in the water area of an underwater quarry under hydro-meteorological situation No. 1 are shown in Figures 4, 5.

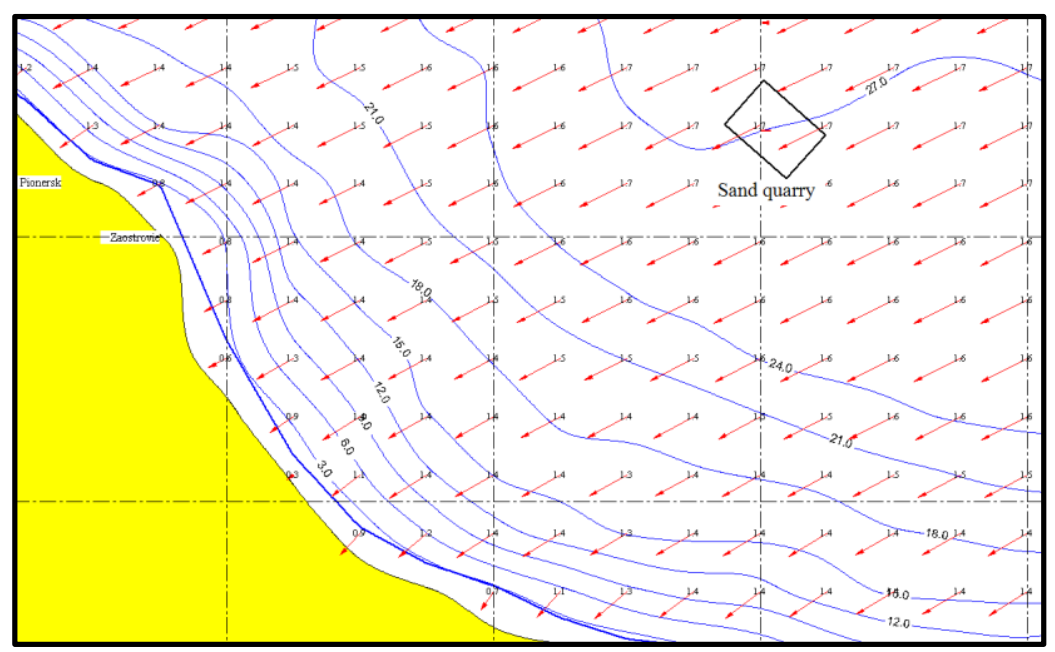

Fig. 4. Field of average wave heights in the water area of the location of the underwater quarry with wind from the NNE direction at a speed of $11 \mathrm{~m} / \mathrm{s}$ for 12 hours.

The results of modeling hydro-meteorological situations are summarized in table 1 .

Table 1. Summary results of hydrometeorological situations modeling.

\begin{tabular}{|c|c|c|c|c|c|c|c|}
\hline \multirow{2}{*}{$\begin{array}{c}\text { No. } \\
\text { hydro- } \\
\text { met. sit. }\end{array}$} & \multicolumn{3}{|c|}{ Wind } & \multicolumn{2}{c|}{ Wave } & \multicolumn{2}{c|}{ Current } \\
\cline { 2 - 8 } & bearing & $\begin{array}{c}\text { Speed. } \\
\mathrm{m} / \mathrm{s}\end{array}$ & $\begin{array}{c}\text { Duration. } \\
\text { hour }\end{array}$ & $\begin{array}{c}\text { Height. } \\
\mathrm{m}\end{array}$ & $\begin{array}{c}\text { Direction. } \\
\text { bearing }\end{array}$ & $\begin{array}{c}\text { Speed. } \\
\mathrm{m} / \mathrm{s}\end{array}$ & $\begin{array}{c}\text { Direction. } \\
\text { bearing }\end{array}$ \\
\hline 1 & NNE & 11 & 12 & 1.5 & NNE & 0.26 & SW \\
\hline 2 & NNE & 5 & 12 & 0.4 & NNE & 0.10 & SSW \\
\hline 3 & WNW & 11 & 12 & 1.0 & NNW & 0.24 & E \\
\hline 4 & N & 5 & 12 & 0.3 & NNE & 0.06 & WSW \\
\hline
\end{tabular}

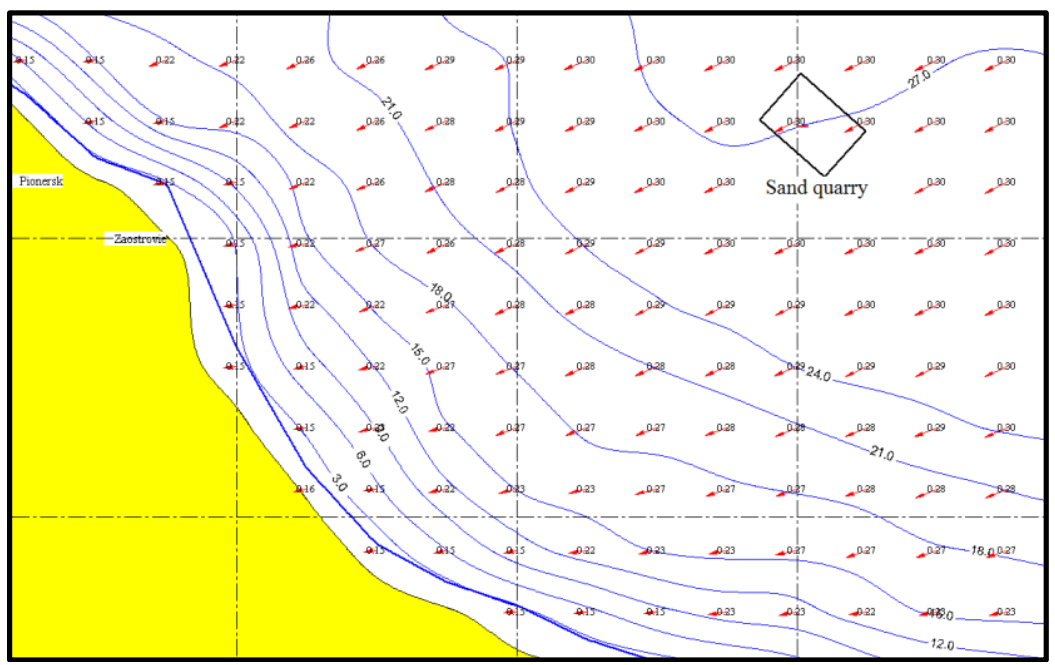

Fig. 5. Field of total currents in the water area of the location of the underwater opencast with wind from the NNE direction at a speed of $11 \mathrm{~m} / \mathrm{s}$ for 12 hours. 


\section{Oil spill transformation modelling}

During engineering surveys in the water area of an underwater sand opencast. it is planned to use the research vessel "Akademik Nikolay Strakhov" with a displacement of 2600 tons. The capacity of the vessel's fuel tanks is 450 tons. Fuel type - diesel fuel. The characteristics of diesel fuel are taken according to the data given in [13]. With the density of diesel fuel $860 \mathrm{~kg} / \mathrm{m} 3$. its volume on the design vessel with a full refueling will be $523 \mathrm{~m} 3$.

The results of modeling the transformation of an accidental spill and drift of an oil products slick for hydro-meteorological situation No. 1 (Table 1) are given in Table 2 and Figure 6.

Table 2. The results of the calculation of the transformation and drift of the accidental diesel fuel spill of the scientific vessel "Akademik Nikolay Strakhov" under hydro-meteorological situation No. 1.

\begin{tabular}{|c|c|c|c|c|c|c|c|c|c|}
\hline $\begin{array}{c}\text { Spill } \\
\text { volume. } \\
\text { V. } \mathbf{M}^{3}\end{array}$ & $\begin{array}{c}\text { Time } \\
\text { after } \\
\text { spill. t. } \\
\text { hour }\end{array}$ & $\begin{array}{c}\text { Wind } \\
\text { speed. } \\
\mathrm{m} / \mathrm{s}\end{array}$ & $\begin{array}{c}\text { Current } \\
\text { speed. } \\
\mathrm{m} / \mathrm{s}\end{array}$ & $\begin{array}{c}\text { Wave } \\
\text { height. } \\
\mathrm{m}\end{array}$ & $\begin{array}{c}\text { Slick } \\
\text { drift } \\
\text { speed. } \\
\mathrm{m} / \mathrm{s}\end{array}$ & $\begin{array}{c}\text { Area of } \\
\text { stains } \\
\text { spill. } \mathrm{M}^{2}\end{array}$ & $\begin{array}{c}\text { Displacement } \\
\text { of the slick } \\
\text { center from } \\
\text { the spill } \\
\text { point. km }\end{array}$ & $\begin{array}{c}\text { Perimeter } \\
\text { of stains } \\
\text { spill. } \mathrm{m}\end{array}$ & $\begin{array}{c}\text { Length of } \\
\text { contamination } \\
\text { line coast. } \\
\mathrm{m}\end{array}$ \\
\hline 523 & 0.2 & 11 & 0.26 & 1.5 & 0.27 & 89459 & 0.2 & 1060 & 0 \\
\hline 523 & 0.5 & 11 & 0.26 & 1.5 & 0.27 & 141447 & 0.5 & 1333 & 0 \\
\hline 523 & 1.0 & 11 & 0.26 & 1.5 & 0.27 & 200036 & 1.0 & 1585 & 0 \\
\hline 523 & 2.0 & 11 & 0.26 & 1.5 & 0.27 & 282894 & 2.0 & 1885 & 0 \\
\hline $\mathbf{5 2 3}$ & $\mathbf{4 . 0}$ & $\mathbf{1 1}$ & $\mathbf{0 . 2 6}$ & $\mathbf{1 . 5}$ & $\mathbf{0 . 2 7}$ & $\mathbf{4 0 0 0 7 2}$ & $\mathbf{4 . 0}$ & $\mathbf{2 2 4 2}$ & $\mathbf{0}$ \\
\hline 523 & 6.0 & 11 & 0.26 & 1.5 & 0.27 & 489986 & 5.9 & 2481 & 0 \\
\hline 523 & 8.0 & 11 & 0.26 & 1.5 & 0.27 & 565787 & 7.9 & 2666 & 0 \\
\hline 523 & 10.0 & 11 & 0.26 & 1.5 & 0.27 & 632569 & 9.9 & 2819 & 0 \\
\hline 523 & 12.0 & 11 & 0.26 & 1.5 & 0.27 & 692945 & 11.9 & 2951 & 1106 \\
\hline
\end{tabular}

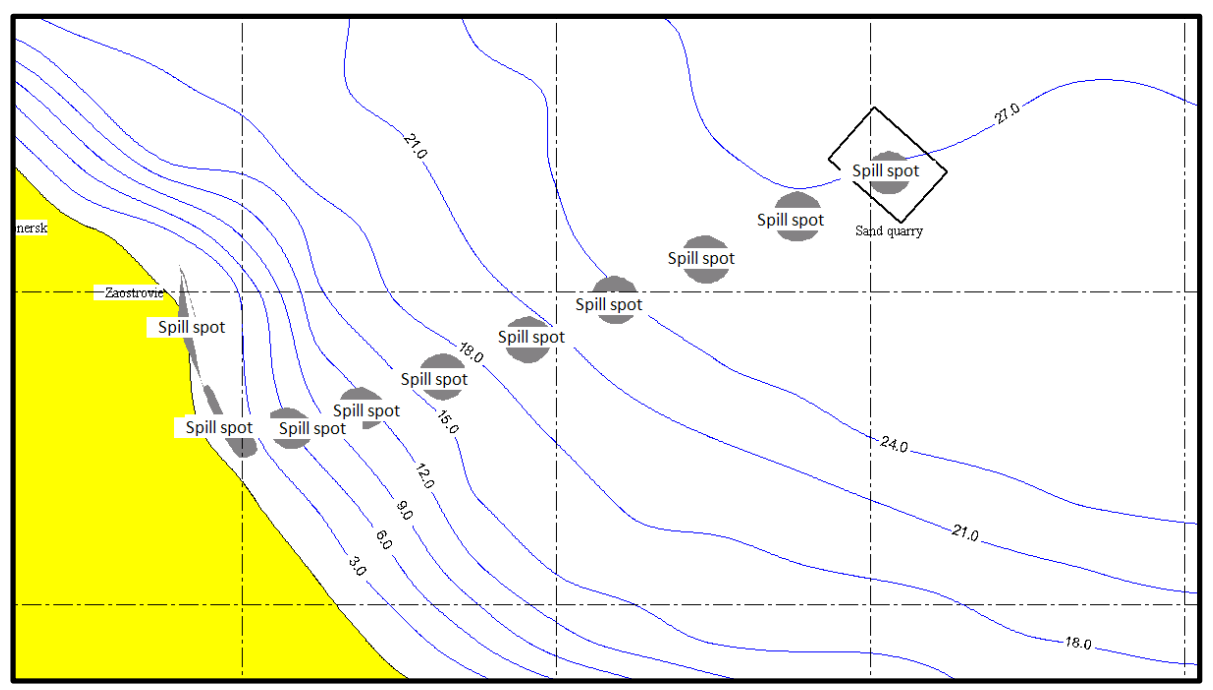

Fig. 6. Drift of the accidental diesel fuel spill of the research vessel "Akademik Nikolay Strakhov" under hydro-meteorological situation No. 1 (12 hours of wind action).

From Table 2 and Figure 6 it follows that in case of hydro-meteorological situation No. 1: 
1. The oil spill slick reaches the coastal zone 11 hours after the accident and starts moving along the coast.

2. With the estimated time of oil spill response 4 hours. the drift of the slick center will be $4 \mathrm{~km}$.

3. The perimeter of the spill slick. which will need to be protected with booms. will be $2242 \mathrm{~m} 4$ hours after the accident.

4. The length of the contaminated shoreline 12 hours after the accident is $1106 \mathrm{~m}$.

The results of modeling the transformation of an accidental spill and drift of an oil slick for hydrometeorological situation No. 2 (Table 1) are shown in Table 3.

Table 3. The results of the calculation of the transformation and drift of the accidental diesel fuel spill of the scientific vessel "Akademik Nikolay Strakhov" under hydro-meteorological situation No. 2.

\begin{tabular}{|c|c|c|c|c|c|c|c|c|c|}
\hline $\begin{array}{c}\text { Spill } \\
\text { volume. } \\
\text { V. } \mathrm{M}^{3}\end{array}$ & $\begin{array}{c}\text { Time } \\
\text { after } \\
\text { spill. t. } \\
\text { hour }\end{array}$ & $\begin{array}{c}\text { Wind } \\
\text { speed. } \\
\mathrm{m} / \mathrm{s}\end{array}$ & $\begin{array}{c}\text { Current } \\
\text { speed. } \\
\mathrm{m} / \mathrm{s}\end{array}$ & $\begin{array}{c}\text { Wave } \\
\text { height. } \\
\mathrm{m}\end{array}$ & $\begin{array}{c}\text { Slick } \\
\text { drift } \\
\text { speed. } \\
\mathrm{m} / \mathrm{s}\end{array}$ & $\begin{array}{c}\text { Area of } \\
\text { stains spill. } \\
\mathrm{M}^{2}\end{array}$ & $\begin{array}{c}\text { Displacement } \\
\text { of the slick } \\
\text { center from } \\
\text { the spill } \\
\text { point. km }\end{array}$ & $\begin{array}{c}\text { Perimeter } \\
\text { of stains } \\
\text { spill. } \mathrm{m}\end{array}$ & $\begin{array}{c}\text { Length of } \\
\text { contamination } \\
\text { line coast. } \\
\mathrm{m}\end{array}$ \\
\hline 523 & 0.2 & 5 & 0.10 & 0.4 & 0.11 & 108245 & 0.1 & 1166 & 523 \\
\hline 523 & 0.5 & 5 & 0.10 & 0.4 & 0.11 & 171151 & 0.2 & 1467 & 523 \\
\hline 523 & 1.0 & 5 & 0.10 & 0.4 & 0.11 & 242044 & 0.4 & 1744 & 523 \\
\hline 523 & 2.0 & 5 & 0.10 & 0.4 & 0.11 & 342301 & 0.8 & 2074 & 523 \\
\hline $\mathbf{5 2 3}$ & $\mathbf{4 . 0}$ & $\mathbf{5}$ & $\mathbf{0 . 1 0}$ & $\mathbf{0 . 4}$ & $\mathbf{0 . 1 1}$ & $\mathbf{4 8 4 0 8 7}$ & $\mathbf{1 . 6}$ & $\mathbf{2 4 6 6}$ & $\mathbf{5 2 3}$ \\
\hline 523 & 6.0 & 5 & 0.10 & 0.4 & 0.11 & 592883 & 2.4 & 2730 & 523 \\
\hline 523 & 8.0 & 5 & 0.10 & 0.4 & 0.11 & 684602 & 3.3 & 2933 & 523 \\
\hline 523 & 10.0 & 5 & 0.10 & 0.4 & 0.11 & 765409 & 4.1 & 3101 & 523 \\
\hline 523 & 12.0 & 5 & 0.10 & 0.4 & 0.11 & 838463 & 4.9 & 3246 & 523 \\
\hline
\end{tabular}

From Table 3 it follows that under hydro-meteorological situation No. 2:

1. In 12 hours the oil spill spot will not reach the coastal zone.

2. With an estimated time for the elimination of an emergency oil spill of 4 hours. the drift of the center of the slick will be $1.6 \mathrm{~km}$.

3. The perimeter of the spill slick. which will need to be protected with booms. will be $2466 \mathrm{~m} 4$ hours after the accident.

Similar calculations were carried out for the operating conditions on the sand career of the "Brabo" self-driving suction dredger. in which the main type of fuel is fuel oil. and the capacity of the fuel tanks is $970 \mathrm{~m} 3$. 4.

In the coastal zone. modeling was performed for hydro-meteorological situations Nos. 3.

The results of modeling the transformation of the emergency fuel oil spill from the "Brabo" dredger and the drift of the slick in the beach reclamation zone under hydrometeorological situation No. 3 are shown in Table 4 and Figure 7.

The simulation results for all considered hydro-meteorological situations and types of floating craft are summarized in Table 5. 
Table 4. The results of the calculation of the transformation and drift of the emergency fuel oil spill from the "Brabo" dredger during the beach reclamation under hydro-meteorological situation No. 3.

\begin{tabular}{|c|c|c|c|c|c|c|c|c|c|}
\hline $\begin{array}{c}\text { Spill } \\
\text { volume. } \\
\text { V. } \mathbf{~}^{3}\end{array}$ & $\begin{array}{c}\text { Time } \\
\text { after } \\
\text { spill. t. } \\
\text { hour }\end{array}$ & $\begin{array}{c}\text { Wind } \\
\text { speed. } \\
\mathrm{m} / \mathrm{s}\end{array}$ & $\begin{array}{c}\text { Current } \\
\text { speed. } \\
\mathrm{m} / \mathrm{s}\end{array}$ & $\begin{array}{c}\text { Wave } \\
\text { height. } \\
\mathrm{m}\end{array}$ & $\begin{array}{c}\text { Slick } \\
\text { drift } \\
\text { speed. } \\
\mathrm{m} / \mathrm{s}\end{array}$ & $\begin{array}{c}\text { Area of } \\
\text { stains } \\
\text { spill. } \mathrm{M}^{2}\end{array}$ & $\begin{array}{c}\text { Displacement } \\
\text { of the slick } \\
\text { center from } \\
\text { the spill } \\
\text { point. km }\end{array}$ & $\begin{array}{c}\text { Perimeter } \\
\text { of stains } \\
\text { spill. } \mathrm{m}\end{array}$ & $\begin{array}{c}\text { Length of } \\
\text { contamination } \\
\text { line coast. } \\
\mathrm{m}\end{array}$ \\
\hline 970 & 0.2 & 11 & 0.22 & 1.0 & 0.24 & 157513 & 0.2 & 1407 & 0 \\
\hline 970 & 0.5 & 11 & 0.22 & 1.0 & 0.24 & 249050 & 0.4 & 1769 & 660 \\
\hline 970 & 1.0 & 11 & 0.22 & 1.0 & 0.24 & 352210 & 0.9 & 2104 & 1160 \\
\hline 970 & 2.0 & 11 & 0.22 & 1.0 & 0.24 & 498101 & 1.7 & 2502 & 1960 \\
\hline $\mathbf{9 7 0}$ & $\mathbf{4 . 0}$ & $\mathbf{1 1}$ & $\mathbf{0 . 2 2}$ & $\mathbf{1 . 0}$ & $\mathbf{0 . 2 4}$ & $\mathbf{7 0 4 4 2 1}$ & $\mathbf{3 . 5}$ & $\mathbf{2 9 7 5}$ & $\mathbf{2 7 6 0}$ \\
\hline 970 & 6.0 & 11 & 0.22 & 1.0 & 0.24 & 862736 & 5.2 & 3293 & 4460 \\
\hline 970 & 8.0 & 11 & 0.22 & 1.0 & 0.24 & 996202 & 7.0 & 3538 & 6260 \\
\hline 970 & 10.0 & 11 & 0.22 & 1.0 & 0.24 & 1113787 & 8.7 & 3741 & 7960 \\
\hline 970 & 12.0 & 11 & 0.22 & 1.0 & 0.24 & 1220093 & 10.5 & 3916 & 9760 \\
\hline
\end{tabular}

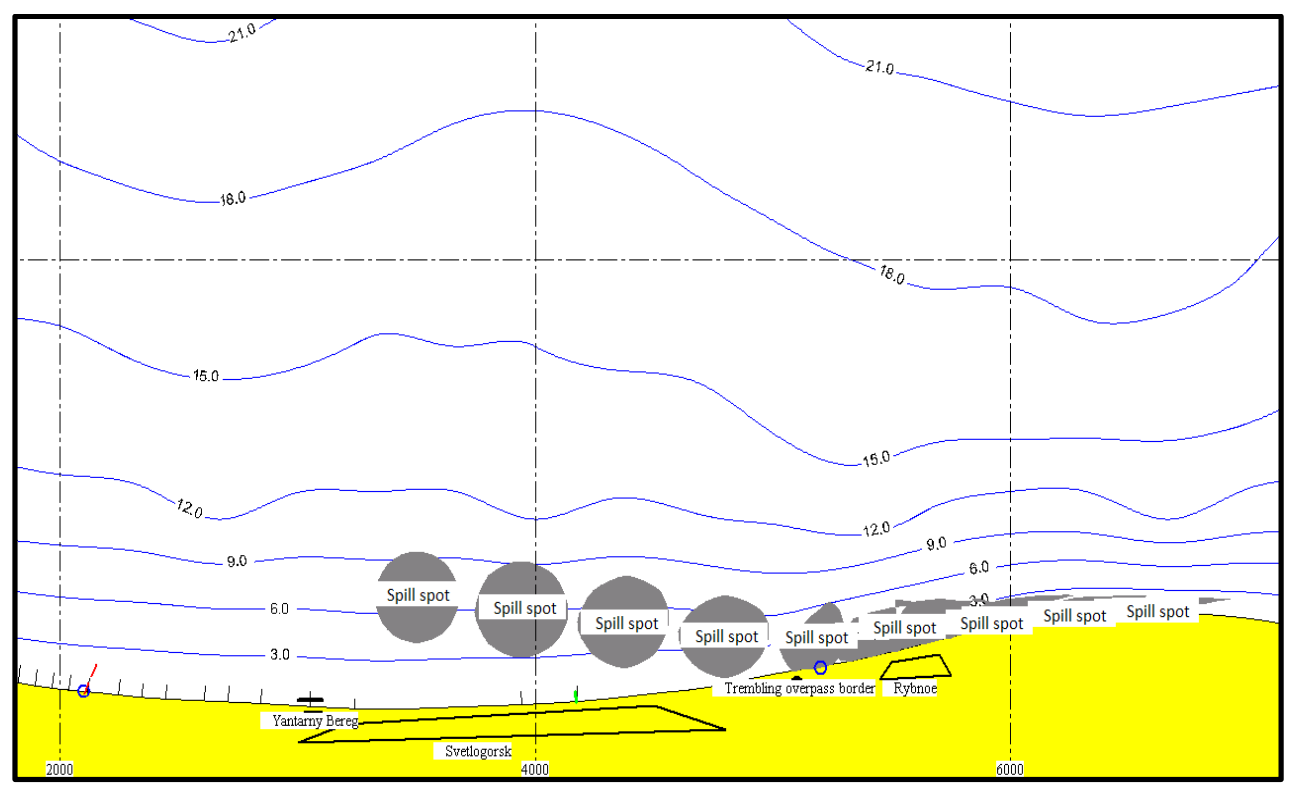

Fig. 7. Drift of the emergency fuel oil spill from the "Brabo" dredger during hydro-meteorological situation No. 3 within 4 hours after the accident. 
Table 5. Main characteristics of accidental oil spills during various types of work and hydrometeorological situations 4 hours after the accident (maximum period before the start of emergency work).

\begin{tabular}{|c|c|c|c|c|c|c|}
\hline $\begin{array}{l}\text { Type of } \\
\text { work }\end{array}$ & Vessel & $\begin{array}{l}\text { No. of hydro- } \\
\text { meteorological } \\
\text { situations }\end{array}$ & $\begin{array}{c}\text { Area } \\
\text { of } \\
\text { stains } \\
\text { spill. } \\
\mathrm{M}^{2} \\
\end{array}$ & $\begin{array}{l}\text { Displacement } \\
\text { of the slick } \\
\text { center from } \\
\text { the spill } \\
\text { point. km }\end{array}$ & $\begin{array}{c}\text { Perimeter } \\
\text { of stains } \\
\text { spill. m }\end{array}$ & $\begin{array}{c}\text { Length of } \\
\text { contamination } \\
\text { line coast. } \\
\mathrm{m}\end{array}$ \\
\hline \multirow{2}{*}{$\begin{array}{l}\text { Engineering } \\
\text { surveys in } \\
\text { an } \\
\text { underwater } \\
\text { quarry }\end{array}$} & \multirow{2}{*}{$\begin{array}{c}\text { Scientific } \\
\text { vessel } \\
\text { "Akademik } \\
\text { Nikolay } \\
\text { Strakhov" }\end{array}$} & 1 & 400072 & 4.0 & 2242 & 0 \\
\hline & & 2 & 484087 & 1.6 & 2466 & 0 \\
\hline \multirow{2}{*}{$\begin{array}{l}\text { Engineering } \\
\text { surveys in } \\
\text { the beach } \\
\text { reclamation } \\
\text { area }\end{array}$} & \multirow[b]{2}{*}{$\begin{array}{l}\text { Sea tug } \\
\text { "Kalmar" }\end{array}$} & 3 & 5042 & 3.5 & 252 & 2200 \\
\hline & & 4 & 6101 & 1.0 & 277 & 180 \\
\hline \multirow{2}{*}{$\begin{array}{c}\text { Sand } \\
\text { mining in } \\
\text { an } \\
\text { underwater } \\
\text { quarry }\end{array}$} & \multirow{2}{*}{$\begin{array}{c}\text { Self- } \\
\text { propelled } \\
\text { bilge } \\
\text { dredger } \\
\text { "Brabo" }\end{array}$} & 1 & 603927 & 3.9 & 2755 & 0 \\
\hline & & 2 & 730752 & 1.6 & 3030 & 0 \\
\hline \multirow{2}{*}{$\begin{array}{l}\text { Alluvium } \\
\text { of the beach }\end{array}$} & \multirow{2}{*}{$\begin{array}{l}\text { Self- } \\
\text { propelled } \\
\text { bilge } \\
\text { dredger } \\
\text { "Brabo" }\end{array}$} & 3 & 704421 & 3.5 & 2975 & 2760 \\
\hline & & 4 & 757567 & 1.07 & 3085 & 1050 \\
\hline
\end{tabular}

\section{Conclusion}

Thus. as a result of mathematical modeling. the main parameters of possible accidental oil spills during engineering surveys. the development of an underwater quarry and beach reclamation in the city of Svetlogorsk. Kaliningrad region. were determined. This data can be used to develop oil spill response plans.

\section{References}

1. Makarov K N 2018 Abstracts of the All-Russian Scientific Conference "Seas of Russia: Methods. Means and Research Results" (Sevastopol) p 268

2. Makarov K N and Katline-Koblev A Kh 2013 Program for calculating wave elements in the coastal zone of the sea in the presence of underwater canyons. Certificate of state registration of a computer program No. 2013618846

3. Makarov K N, Makarov N K, Nikolenko A A and Pogoreltsev Yu R 2014 Program for calculating the dynamics of free beaches and beaches protected by beach-retaining structures. including those on artificial islands. State Registration Certificate No. 2014617856

4. Makarov K N 2008 Mathematical modeling in marine hydraulic engineering (Sochi State University) p 397

5. SP 38.13330.2018 Loads and impacts on hydraulic structures (wave. ice and from ships) (Moscow: Gosstroy RF) p 122

6. RD 52.10.865-2017 Guidelines for the calculation of operating characteristics of sea wind waves (Moscow: Rosgidromet) p 64 
7. 1994 Guide to Marine Hydrological Forecasts (St. Petersburg: Rosgidromet) p 525

8. 1975 Guid for research methods and calculations of sediment movement and coastal dynamics during engineering surveys (Moscow: Hydrometeoizdat) p 239

9. Shadrin I F 1981 Coastal zone of the sea (Moscow: Nauka) p 40

10. Sudolsky A S 1991 Dynamic phenomena in water bodies (Leningrad: Hydrometeoizdat) p 262

11. 2003 Dynamic processes of the coastal zone of the sea (Moscow: Nauchny Mir) p 320

12. Longuet - Higgins M S 1974 Surf zone mechanics. - "Mechanics" (Moscow: Mir) p 84

13. Matsenko S V, Volkov G G and Volkova T A 2009 Elimination of spills of oil and oil products at sea and inland waters. Calculation of the sufficiency of forces and means. Guidelines (Novorossiysk: Maritime State Academy) p 156

14. 2016 Methodological recommendations for predicting the spread of oil and oil products in the event of an accidental spill in offshore areas (Roshydromet SOIN) p 135

15. 1995 Guidelines for Oil Pollution Control: Section II Emergency Planning IMO - 560E ISBN 92-80-1330-5

16. 1988 Guidelines for Oil Pollution Control: Section IV Oil Pollution Control IMO - 569E ISBN 92-801-1242-2

17. 1998 Oil Pollution Control Guidelines: Section VI IMO Guidelines for Sampling and Oil Spill Identification IMO - 578E ISBN 92-801-1451-4

18. 1998 Guidelines for Oil Pollution Abatement: Section V Oil Pollution Administration Administrative Matters IMO - 572E ISBN 92-801-1424-7

19. 2012 Behavior of offshore oil spills. Technical white paper ITOPF

20. Perezhogin D Yu 2019 Methodological bases for assessing fire risks in the oil spill area in the offshore area. Diss. Cand. Tech. sciences (Ufa State Petroleum Technical University)

21. Zatsepa S N 2014 Arctic: ecology and economy 4(16) 68 